\title{
The Pharmacological Effect and Mechanism of Lanthanum Hydroxide on Vascular Calcification Caused by Chronic Renal Failure Hyperphosphatemia
}

\author{
Lulu Zhao ${ }^{1}$, Sheng-Nan Wang ${ }^{1}$, Hong Liu ${ }^{1}$, Xiao-Li Du ${ }^{1}$, Ren Bu ${ }^{1}$, Bing Li $^{1}$, Rui-Lan \\ $\mathrm{Han}^{1}$, Jie Gao ${ }^{1}$, Yang Liu ${ }^{1}$, Jian $\mathrm{Hao}^{2}$, Jianrong Zhao ${ }^{3}$, Yan Meng ${ }^{2}$, and Gang $\mathrm{Li}^{1}$ \\ ${ }^{1}$ Inner Mongolia Medical University \\ ${ }^{2}$ Department of Nephrology, The Affiliated Hospital of Inner Mongolia Medical University \\ ${ }^{3}$ Renal Division, Department of Medicine, Peking University First Hospital; Institute of \\ Nephrology, Peking University; Key Laboratory of Renal Disease, Ministry of Health of \\ China
}

November 4, 2020

\begin{abstract}
Background and Purpose: To investigate the treatment and mechanism of lanthanum hydroxide on hyperphosphate-induced vascular calcification in chronic renal failure. Experimental Approach: Develop a rat model of CKD hyperphosphatemia. Rats were randomly allocated to the model, lanthanum hydroxide, lanthanum carbonate, Calcium carbonate groups. Determination of serum biochemical indicators and the determination of pathological analysis of kidney tissue, Von Kossa staining and CT scan on the aortic vessels. The proteomic analysis of aortic tissue in Vivo. A calcified VSMCs model was established. The calcium content and ALP activity were measured. RT-PCR measures the mRNA expression level of SM22 $\alpha$, Runx2, BMP-2 and TRAF6. Western Blot measures the protein expression level of SM22 $\alpha$, Runx2, BMP-2, TRAF6 and NF- $\chi$ B. Key Results: Through the detection of serum biochemical indicators and pathological analysis of kidney tissue, it can be summaryed that lanthanum hydroxide has the effect of delaying the progression of renal failure and protecting renal function. We found that the administration of lanthanum hydroxide delayed the development of vascular calcification induced by hyperphosphatemia in CKD. It can be concluded that lanthanum hydroxide may affect vascular calcification through the NF- $\varkappa \mathrm{B}$ pathway. In cultured VSMCs, treatment with Lanthanum chloride ( $\mathrm{LaCl} 3$ ) blunted phosphate-induced calcification, osteo-/chondrogenic signaling, and NF- $x$ B activation. Lanthanum hydroxide significantly reduces the expression of Runx2, BMP-2, TRAF6 and NF- $x$ B. Conclusion and Implications: Lanthanum hydroxide has a protective effect on the kidneys, and can delay the development of vascular calcification by reducing serum phosphorus concentration. KEYWORDS: Lanthanum hydroxide, vascular calcification, chronic renal failure, hyperphosphatemia, pharmacological effect, mechanism
\end{abstract}

\section{Hosted file}

Main Document.pdf available at https://authorea.com/users/372885/articles/490737-thepharmacological-effect-and-mechanism-of-lanthanum-hydroxide-on-vascular-calcificationcaused-by-chronic-renal-failure-hyperphosphatemia

\section{Hosted file}

Figure 1.pptx available at https://authorea.com/users/372885/articles/490737-thepharmacological-effect-and-mechanism-of-lanthanum-hydroxide-on-vascular-calcificationcaused-by-chronic-renal-failure-hyperphosphatemia 


\section{Hosted file}

Figure 2.pptx available at https://authorea.com/users/372885/articles/490737-thepharmacological-effect-and-mechanism-of-lanthanum-hydroxide-on-vascular-calcificationcaused-by-chronic-renal-failure-hyperphosphatemia

\section{Hosted file}

Figure 3.pptx available at https://authorea.com/users/372885/articles/490737-thepharmacological-effect-and-mechanism-of-lanthanum-hydroxide-on-vascular-calcificationcaused-by-chronic-renal-failure-hyperphosphatemia

\section{Hosted file}

Figure 4.pptx available at https://authorea.com/users/372885/articles/490737-thepharmacological-effect-and-mechanism-of-lanthanum-hydroxide-on-vascular-calcificationcaused-by-chronic-renal-failure-hyperphosphatemia

\section{Hosted file}

Figure 5.pptx available at https://authorea.com/users/372885/articles/490737-thepharmacological-effect-and-mechanism-of-lanthanum-hydroxide-on-vascular-calcificationcaused-by-chronic-renal-failure-hyperphosphatemia

\section{Hosted file}

Figure 6.pptx available at https://authorea.com/users/372885/articles/490737-thepharmacological-effect-and-mechanism-of-lanthanum-hydroxide-on-vascular-calcificationcaused-by-chronic-renal-failure-hyperphosphatemia

\section{Hosted file}

Figure 7.pptx available at https://authorea.com/users/372885/articles/490737-thepharmacological-effect-and-mechanism-of-lanthanum-hydroxide-on-vascular-calcificationcaused-by-chronic-renal-failure-hyperphosphatemia

\section{Hosted file}

Figure 8.pptx available at https://authorea.com/users/372885/articles/490737-thepharmacological-effect-and-mechanism-of-lanthanum-hydroxide-on-vascular-calcificationcaused-by-chronic-renal-failure-hyperphosphatemia

\section{Hosted file}

Figure 9.pptx available at https://authorea.com/users/372885/articles/490737-thepharmacological-effect-and-mechanism-of-lanthanum-hydroxide-on-vascular-calcificationcaused-by-chronic-renal-failure-hyperphosphatemia

\section{Hosted file}

Figure 10.pptx available at https://authorea.com/users/372885/articles/490737-thepharmacological-effect-and-mechanism-of-lanthanum-hydroxide-on-vascular-calcificationcaused-by-chronic-renal-failure-hyperphosphatemia

\section{Hosted file}

Supplementary Figure S1.pptx available at https://authorea.com/users/372885/articles/ 490737-the-pharmacological-effect-and-mechanism-of-lanthanum-hydroxide-on-vascularcalcification-caused-by-chronic-renal-failure-hyperphosphatemia

\section{Hosted file}


Supplementary Figure S2.pptx available at https://authorea.com/users/372885/articles/ 490737-the-pharmacological-effect-and-mechanism-of-lanthanum-hydroxide-on-vascularcalcification-caused-by-chronic-renal-failure-hyperphosphatemia

Hosted file

Supplementary Figure S3.pptx available at https://authorea.com/users/372885/articles/ 490737-the-pharmacological-effect-and-mechanism-of-lanthanum-hydroxide-on-vascularcalcification-caused-by-chronic-renal-failure-hyperphosphatemia 